\title{
Minimizing 50\% of Chemical Npk Fertilizers by Compost and Em and Their Impact on Growth, Nutritional Status, Productivity and Fruit Quality of Washington Navel Orange Trees
}

\author{
A. A. EL-Khwaga ${ }^{1}$, F. M. Abd El-Latif ${ }^{1}$, M. H. M. Baiea ${ }^{2}$, and S. F. EL-Gioushy ${ }^{1, *}$ \\ ${ }^{1}$ Horticulture Department, Faculty of Agriculture (Moshtohor), Benha University, Moshtohor, \\ Toukh, 13736, Egypt. \\ ${ }^{2}$ Horticultural Crops Technology Dept. National Research Centre. Dokki. Giza. Egypt. \\ *Corresponding author: Sherif.elgioushy@fagr.bu.edu.eg, gioushy_ah@yahoo.com,
}

\begin{abstract}
This research was conducted during the 2018 and 2019 seasons on 9-year-old Washington navel orange trees budded on Sour orange rootstock planted 5 x 5 meters apart under the surface irrigation of a private orchard in Manzala Village, Toukh Area, Qalubia Governorate, Egypt. The five treatments used in this experiment is defined as follows: T1-100\% of chemical NPK, $\mathrm{T}_{2}-50 \%$ of chemical NPK + compost @ 2 ton /fed, $\mathrm{T}_{3}-50 \%$ of chemical $\mathrm{NPK}+$ compost @ 2 tons/fed. + EM @ 20ml per tree, $\mathrm{T}_{4}-50 \%$ of chemical NPK + compost @ 3 ton/fed and $\mathrm{T}_{5}$ - 50\% of chemical NPK + compost @ 3 ton/fed + EM @ 20ml per tree. The main goal was directed towards increasing growth of Washington navel orange trees, and fruiting aspects associated with lower its production cost through investigating the minimizing of chemical NPK fertilizers by compost and EM. Data obtained showed that all the evaluated treatments increased the growth parameters as well as the total chlorophyll and nutritional status of the leaf were also positively responded, fruit set $\%$, yield/tree and fruit quality were also improved. However, T1-100\% of chemical NPK and $\mathrm{T}_{5^{-}} 50 \%$ of chemical NPK + compost @ 3 ton/fed. + EM @ 20ml per tree was statistically superior. Moreover, T4 - 50\% of chemical NPK + compost @ 3 tons/fed ranked statistically second in this concern.
\end{abstract}

Keywords: Washington Navel Orange, Minimizing, compost, EM, Productivity, and Fruit Quality.

\section{Introduction}

Citrus trees have a major economic significance among fruit crops in Egypt in terms of cultivated area, output and export potential. Egypt is considered to be the world's largest orange exporter and ranked as the sixth-largest producer. Orange is the largest citrus species in Egypt, where approximately 133,236 hectares are planted, accounting for about $69 \%$ of the total citrus area, producing about 2.9 million tons, accounting for about 71 percent of total citrus production, exporting about 1.1 million tons of orange, accounting for about 92 percent of total citrus exports, (Annual Reports of Statistical Institute and Agricultural Economic Research in Egypt, 2016)

There are different problems of navel orange productivity in the Delta zone, such as (1) Lack of sufficient quantity of fertilizers, still, mostly no prescribed fertilization programmers, (2) There are vast areas with low productivity due to the Sinensis crop, some of these orchards planting more than 50 years ago, (3) (3) Low productivity of different orchards (around 22 tons/ha) (4) Most orchards in the Delta area have mixed varieties within the same sector, Abobatta (2018).

The majority of the Navel orange field planted is concentrated in the Delta governorates (Gharbia, Qalyoubia, Menoufia, Sharqiya and Ismailia) which are known to be the main production areas. Navel orange ranks first among citrus varieties, accounting for 60 percent of all planted areas and 60 percent of overall orange production. On the other hand, Navel orange is the most popular cultivar in Egypt and is considered a popular fresh citrus fruit for Egyptians due to its seedless, large size and flavor and aroma characteristics, high-quality fruit, favorable taste and low prices compared to other fruits, Navel orange is the key source of early-season income for citrus growers in the Delta region. The Navel is the first orange on the market to ripen between December and February. With its trademark round shape and deep orange hue, the easy-to-peel navel is one of the most common varieties in the world of Abobatta (2018).

The organic content of compost is high and its addition to soil also increases soil physical and chemical properties and promotes biological activity. Many of the agricultural advantages of soil composting are extracted from enhanced physical properties due to an improvement in organic matter quality rather than its importance as fertilizer. Compost provides a stabilized type of organic matter that enhances soil physical properties by increasing soil nutrient and water holding potential, total pore space, aggregate stabilization, erosion tolerance, temperature insulation and decreasing visible soil density. The use of compost increases the chemical properties by increasing action exchangeability and soil nutrient content. (Shiralipour et al., 1992).

Compost is a widely available nutrient with beneficial effects on soil physical, chemical, biochemical and biological properties. Also, compostbased therapies can protect against the emergence of plant diseases and/or promote improved plant 
physiological status by improving the quantity and quality of crop production. (Loredana et al., 2015).

Recently, bio fertilization is used as a method to increase the yield and fruit quality of citrus and is a positive alternative to chemical fertilizers. It is healthy for humans and the ecosystem, and its use has been followed by a decline in the high emissions that have arisen in our environment as well as the cultivation of organic food for export. The application of organic fertilizers in the citrus orchard is a production system that avoids or largely excludes the use of synthetic chemical fertilizers (Abdelaal et al., 2010).

The technology was invented by Professor Teruo Higa, University of Ryukyus, Okinawa, Japan, who isolated certain beneficial micro-organisms from the soil and named them an important micro-organism (EM) and marketed by the EM Research Organization (Higa, 1986). Besides, EM includes selected microorganism groups, including three major categories of pathogens, namely lactic acid bacteria, Actinomyces of yeast and photosynthetic bacteria usually present in soils (Higa, 1991).

Effective microorganisms (EM1) It is a biofertilizer, the basic aim of EM is to restore a balanced environment in both soil and water by using three main genera of microorganisms present in nature: phototrophic bacteria (Rhodopseudomonas), lactic acid bacteria. (Lactobacillus) and yeast (Saccharomyces). EM contains Lactobacillus plantarum, L. casei, L. fermentum, L. delbrueckii, Saccharomyces cerevisiaeand Rhodopseudomonas palustris (Abd-Rabou, 2006 and Higa, 2010). Higher yield in the EM treatments can be correlated with improved soil chemical and physical conditions, determined by the use of effective microorganisms at the time the citrus plants were in bloom and fruits were forming in late winter (Paschoal et al., 1999).

The main goal was directed towards increasing Washington navel orange trees growth, nutritional status, productivity and fruit quality associated with lower its production cost and consequently net grower's income of such favorable cultivar through investigating the minimizing $50 \%$ of chemical NPK fertilization by using compost and EM.

\section{Materials and Methods}

This research was conducted during the 2018 and 2019 seasons on 9-year-old Washington navel orange trees budded on Sour orange rootstock planted 5 × 5 meters apart (168 trees/fed.) under private orchard irrigation in Manzala Village, Toukh Region, Qalubia Governorate, Egypt. All trees have been subjected to the same horticultural practices (irrigation, fertilization, weeds and pest control) introduced in the region as recommended by the Ministry of Agriculture and Land Reclamation; (2015). It has been committed to investigating the effect of chemical NPK fertilization, compost and EM on the growth, Nutrition status, production and fruit content of Washington navel orange trees. Before the start of the 1st season (2018) a mechanical and chemical study of the orchard soil surface $(0.40 \mathrm{~cm}$. depth) was carried out according to Black et al., (1982). As shown in Table (A) and analyses of used composted materials in Table (B).

Table A. Physical and chemical properties of the investigated soil.

\begin{tabular}{|c|c|c|c|c|c|}
\hline \multirow{3}{*}{$\begin{array}{l}\text { Physical analysis } \\
\text { Coarse sand }\end{array}$} & \multirow{3}{*}{$\begin{array}{l}\text { Value } \\
11 \%\end{array}$} & \multicolumn{4}{|c|}{ Chemical analysis } \\
\hline & & \multicolumn{2}{|c|}{ Cations meq/l } & \multicolumn{2}{|c|}{ Anions meq/l } \\
\hline & & $\mathrm{Ca}^{++}$ & 8.8 & $\mathrm{CO}^{--}$ & Zero \\
\hline Fine sand & $18.2 \%$ & $\mathrm{Mg}^{++}$ & 3.25 & $\mathrm{HCO}^{-}$ & 4.5 \\
\hline Silt & $19.2 \%$ & $\mathrm{Na}^{+}$ & 4.30 & $\mathrm{Cl}^{-}$ & 6.45 \\
\hline Clay & $50.4 \%$ & $\mathrm{~K}^{+}$ & 1.08 & $\mathrm{SO}^{--}$ & 8.00 \\
\hline Texture class & Clay loam & \multicolumn{4}{|c|}{ Available N $24.5 \mathrm{mg} / \mathrm{kg}$} \\
\hline Soil pH & 7.2 & \multicolumn{4}{|c|}{ Available P $11.94 \mathrm{mg} / \mathrm{kg}$} \\
\hline E.C, ds/m & 1.60 & \multirow{2}{*}{\multicolumn{4}{|c|}{ Available K $170.5 \mathrm{mg} / \mathrm{kg}$}} \\
\hline Organic matter & $3.4 \%$ & & & & \\
\hline
\end{tabular}

Table B. Analysis of the used composted material (compost).

\begin{tabular}{|c|c|c|c|c|c|c|c|c|c|c|c|c|c|c|c|c|}
\hline $\begin{array}{c}\text { Paramet } \\
\text { er }\end{array}$ & $\begin{array}{c}\text { M3 } \\
\text { weig } \\
\text { ht }\end{array}$ & $\begin{array}{c}\text { Moistu } \\
\text { re } \\
\%\end{array}$ & $\begin{array}{c}\text { PH } \\
(1: 1 \\
0)\end{array}$ & $\begin{array}{l}\text { EC } \\
(\mathrm{ds} / \\
\mathrm{m})\end{array}$ & $\begin{array}{l}\text { Organ } \\
\text { ic } \\
\text { matter }\end{array}$ & $\begin{array}{c}\mathrm{C} / \mathrm{N} \\
\text { rati } \\
\mathbf{0}\end{array}$ & $\begin{array}{c}\text { Organ } \\
\text { ic } \\
\text { carbo } \\
\text { n \% }\end{array}$ & $\begin{array}{c}\text { Tot } \\
\text { al } \\
\text { N\% }\end{array}$ & $\begin{array}{c}\text { Tot } \\
\text { al } \\
\text { P\% }\end{array}$ & $\begin{array}{c}\text { Tot } \\
\text { al } \\
\text { K\% }\end{array}$ & $\begin{array}{c}\text { Tot } \\
\text { al } \\
\text { Ca } \\
\%\end{array}$ & $\begin{array}{c}\text { Tota } \\
\mathbf{l} \\
\mathbf{M g} \\
\%\end{array}$ & $\begin{array}{l}\text { Tota } \\
\text { l Fe } \\
\text { (pp } \\
\text { m) }\end{array}$ & $\begin{array}{c}\text { Tota } \\
\text { l Mn } \\
\text { (pp } \\
\text { m) }\end{array}$ & $\begin{array}{c}\text { Tota } \\
\mathbf{l} \\
\mathbf{Z n} \\
\text { (pp } \\
\text { m) } \\
\end{array}$ & $\begin{array}{l}\text { Tota } \\
\text { l Cu } \\
\text { (pp } \\
\text { m) }\end{array}$ \\
\hline Value & $\begin{array}{c}790 \\
\mathrm{~kg} \\
\end{array}$ & 30 & 8.9 & 3.4 & 35.6 & $\begin{array}{c}17 . \\
6\end{array}$ & 26.4 & 1.5 & 0.6 & 1.32 & 1.93 & 0.90 & 1012 & 116 & 28 & 18.3 \\
\hline
\end{tabular}

\section{Rate and application method of different NPK fertilization sources:}

In this experiment, two rates of NPK chemical fertilizers were used. The first-rate was $100 \%$ of NPK chemical (5, 3 and $1 \mathrm{~kg}$ per tree, respectively). The second rate was 50 percent of the chemical NPK (2.5, 1.5 , and $0.50 \mathrm{~kg}$ per tree, respectively), applied in four similar batches in the first week of February, April, 
June and July ( 2 and 3 tons per feddan). As well as, $\mathrm{EM}$ at the rate of $20 \mathrm{ml} /$ tree they were added once during the first week of December.

\section{The five treatments involved in this study were} summarized as follows:

$\mathrm{T}_{1}-100 \%$ Chemical NPK (as fertilization program adopted at 5,3 , and $1 \mathrm{~kg} /$ tree from $\left(\mathrm{NH}_{4}\right)_{2} \mathrm{SO}_{4}$, superphosphate and $\mathrm{K}_{2} \mathrm{SO}_{4}$, respectively) according to the Ministry of Agriculture and Land Reclamation, (2015) Recommendation (Control).

$\mathrm{T}_{2}-50 \%$ Chemical NPK + compost (2 tons/ feddan). $\mathrm{T}_{3}-50 \%$ Chemical NPK + compost (2 tons/ feddan) $+\mathrm{EM}$ at $20 \mathrm{ml} /$ tree.

$\mathrm{T}_{4}-50 \%$ Chemical NPK + compost (3 tons/ feddan).

$\mathrm{T}_{5}-50 \%$ Chemical NPK + compost ( 3 tons/ feddan) $+\mathrm{EM}$ at $20 \mathrm{ml} /$ tree.

\section{Experiment layout:}

The complete randomized block design with three replications was employed for arranging the five investigated fertilization treatments, whereas a single tree represented each replicate. Consequently, 15 healthy fruitful Washington navel orange trees were carefully selected, as being healthy, disease-free and in the on-year state. Chosen trees were divided according to their growth vigor into three categories (blocks) each included five similar trees for receiving the investigated five fertilization treatments (a single tree was randomly subjected to one treatment).

As reported in this research, the technique for assessing the reaction to the various treatments investigated was carried out by deciding improvements in the different measures of the following characteristics examined:

In late March 2018 and 2019, during the 1st and 2nd seasons, four large branches (limbs/scaffolds) well-spaced along each tree periphery were carefully selected and tagged. In addition, 20 freshly produced shoots for spring were also labeled.

Vegetative growth parameters:

In mid-October, the following vegetative growth parameters were determined during the $1^{\underline{\text { st }}}$ and $2^{\underline{\text { nd }}}$ experimental seasons, respectively.

In this regard, the average number of newly developed shoots per one meter of every tagged limb, average (length \& thickness), and the number of leaves, per each labeled shoot was estimated. Besides, average leaf area $\left(\mathrm{cm}^{2}\right)$ on a weight basis was also determined. Hence, twenty mature leaves from the previously labeled shoots per each limb were randomly collected. Then 20 disks each of one $\mathrm{cm}$. the area was taken and oven-dried together with the rest leaves at $80^{\circ} \mathrm{C}$ till constant weight. Based on the known dry weight of a known surface area of leaves, i.e., 20 leaf discs from one hand and the total weight of 20 leaves from the other, the average leaf area in $\mathrm{cm}$. was calculated. Moreover, assimilation area per one shoots according to the following equation: Assimilation area $=$ leaf area $\mathrm{x}$ No. of leaves per one shoot.

\section{Nutritional status measurements:}

Total chlorophyll content:

Total chlorophyll content in fresh leaves was determined by using Minolta meter SPAD502.

\section{Leaf mineral composition:}

Representative samples of fourth and fifth leaves from the base of spring shoots were collected from each replicate in October during both seasons. The samples were thoroughly washed with tap water, rinsed twice with distilled water and oven-dried at $80^{\circ} \mathrm{C}$ till a constant weight and finely ground for determination of:

a. Total Nitrogen: Total leaf $(\mathrm{N})$ was determined by the modified micro Keldahl method mentioned by (Pregl, 1945).

b. Total phosphorus: Total leaf $(\mathrm{P})$ was determined by wet digestion of plant materials after the methods described by using sulphuric and perchloric acid, which has been strongly recommended by (Piper, 1958).

c. Total potassium: Total leaf $(\mathrm{K})$ was determined photometrically in the digested material according to the method described by (Brown and Lilliand, 1946).

d. Calcium and $\mathrm{Mg}$ percentage, as well as Iron, Manganese, and Zinc, were determined using the Atomic absorption spectrophotometer "Perkin Elmer -3300" after Chapman and Pratt (1961).

\section{Productivity parameters:}

\section{Fruit set percentage:}

At full bloom during each experimental season, the number of perfect flowers per tagged limb was counted. After $75 \%$ of petal fall fruit set as a percentage of perfect flowers were estimated according to the following equation:

$$
\text { Number of set fruitlets }
$$

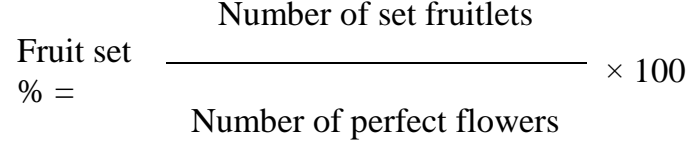

Fruits retention \%:

At a given date in December during each experimental season Percentage of retained fruits were estimated according to the following equations:

Number of presented

\begin{tabular}{|c|c|}
\hline $\begin{array}{l}\text { Fruits } \\
\text { etention }\end{array}$ & $\begin{array}{l}\text { (remained) fruits at a given } \\
\text { date }\end{array}$ \\
\hline & Number of set fruitlets \\
\hline
\end{tabular}

Yield:

In late-December 2018 and 2019, fruits of each tree were separately harvested, then counted and weighed. Tree productivity (yield) was estimated as 
either the number or weight $(\mathrm{kg})$ of harvested fruits per tree. Besides, yield per tree.

\section{Fruit quality:}

\section{Fruit physical properties:}

In this regard, average fruit weight (g.); dimensions (polar \& equatorial diameters i.e., length \& width in cm. \& mm.); fruit shape index (length: width); juice volume and juice percentage and peel/rind thickness (mm) were the fruit physical characteristics investigated in this regard.

\section{Fruit chemical properties:}

Fruit juice, total soluble solids percentage (TSS $\%$ ) was determined using Carl Zeins hand refractometer. fruit total acidity (grams of citric acid per $100 \mathrm{ml}$ of juice and ascorbic acid (V.C) content (milligrams ascorbic acid per 100ml fruit juice) was determined after A.O.A.C., 1995. The total soluble solids/acid ratio was also estimated. Ascorbic, acid/vitamin $\mathrm{C}$ content was determined using 2, 6 dichlorophenol indophenol indicator for titration after A.O.A.C., 1995. Moreover, total sugars\% was determined after the method described by Smith et al. (1956).

\section{Statistical analysis:}

According to (Snedecor and Cochran, 1980), all data collected during both seasons for this experiment included in this investigation were subjected to analysis of variance. In addition, major variations between means were distinguished according to the Duncan, multiple test range (Duncan, 1955) where capital letter/s were used for distinguishing means of different treatments for each investigated characteristic.

\section{Results}

\section{Vegetative growth measurements:}

In this respect number of developed shoots per one meter of each tagged main branch (limb/scaffold), average shoot length $\&$ diameter, number of leaves per shoot, average leaf area and total assimilation area per shoot were the investigated growth parameters in response to the differential treatments. Data obtained during both the 2018 and 2019 seasons are presented in Tables (1 and 2).

Concerning the response of the abovementioned vegetative growth parameters to the differential investigated treatments; Tables (1 and 2) show a considerable variation in this respect. Herein, the highest values were significantly coupled with the Washington navel orange trees subjected to $\mathrm{T}_{1}-100 \%$ of chemical NPK. Moreover, $\mathrm{T}_{5^{-}} 50 \%$ Chemical + compost (3 tons) + EM showed significantly the same effectiveness in this concern. Moreover, the $4^{\text {th }}$ treatment $(50 \%$ of chemical NPK + compost at the rate of 3 tons) ranked statistically $2^{\underline{n} \text { nd }}$ on its efficiency. On the contrary, the least values of the abovementioned parameters were usually concomitant to $\mathrm{T}_{2}-50 \%$ Chemical NPK + compost (2 tons), which ranked statistically last during both seasons of study.

Table 1. Effectiveness of mineral NPK, compost and EM on the number of new shoots, shoot length and shoot diameter of Washington navel orange trees during 2018 \& 2019 seasons.

\begin{tabular}{|c|c|c|c|c|c|c|}
\hline \multirow{2}{*}{ Treatments } & \multicolumn{2}{|c|}{ No. of new shoots } & \multicolumn{2}{|c|}{ Shoot length $(\mathrm{cm})$} & \multicolumn{2}{|c|}{ Shoot Diameter (mm) } \\
\hline & 2018 & 2019 & 2018 & 2019 & 2018 & 2019 \\
\hline T1- Control (100\% chemical). & $26.33 \mathrm{~A}$ & $25.33 \mathrm{~A}$ & $36.33 \mathrm{~A}$ & $36.33 \mathrm{~A}$ & $1.17 \mathrm{~A}$ & $3.16 \mathrm{~A}$ \\
\hline T2 - 50\% Chemical NPK + compost ( 2 tons) & 17.67 B & 17.33 C & 27.33 D & 25.67 E & $2.93 \mathrm{E}$ & $2.60 \mathrm{D}$ \\
\hline T3 - 50\% Chemical NPK+ compost ( 2 tons) + EM & 20.67 B & $21.33 \mathrm{~B}$ & $30.33 \mathrm{C}$ & 28.00 D & $2.99 \mathrm{D}$ & $2.74 \mathrm{C}$ \\
\hline T4 $-50 \%$ Chemical NPK + compost ( 3 tons) & $24.67 \mathrm{~A}$ & $23.67 \mathrm{~A}$ & 34.00 B & $32.67 \mathrm{C}$ & $3.05 \mathrm{C}$ & $2.86 \mathrm{~B}$ \\
\hline T5 - 50\% Chemical NPK + compost ( 3 tons) + EM & $25.67 \mathrm{~A}$ & $24.33 \mathrm{~A}$ & $35.67 \mathrm{~A}$ & $35.00 \mathrm{~B}$ & 3.13 B & $3.17 \mathrm{~A}$ \\
\hline
\end{tabular}

Means followed by the same letter/s within each column didn't significantly differ at $5 \%$ level.

Table 2. Effectiveness of mineral NPK, compost and EM on the number of leaves/shoot, Leaf area and Assimilation area of Washington navel orange trees during 2018 \& 2019 seasons.

\begin{tabular}{|c|c|c|c|c|c|c|}
\hline \multirow{2}{*}{ Treatments } & \multicolumn{2}{|c|}{ No. of leaves/shoot } & \multicolumn{2}{|c|}{$\begin{array}{l}\text { Leaf area } \\
\quad\left(\mathrm{cm}^{2}\right)\end{array}$} & \multicolumn{2}{|c|}{$\begin{array}{l}\text { Assimilation area } \\
\left(\mathrm{m}^{2} / \mathrm{shoot}\right)\end{array}$} \\
\hline & 2018 & 2019 & 2018 & 2019 & 2018 & 2019 \\
\hline T1- Control (100\% chemical). & $36.00 \mathrm{~A}$ & $35.67 \mathrm{~A}$ & $18.53 \mathrm{~A}$ & $18.52 \mathrm{~A}$ & $7.23 \mathrm{~A}$ & $6.61 \mathrm{~A}$ \\
\hline $\begin{array}{l}\text { T2 - 50\% Chemical NPK + compost ( } 2 \text { tons) } \\
\text { T3 - 50\% Chemical NPK + compost ( } 2 \text { tons) }+ \text { EM }\end{array}$ & $\begin{array}{l}\text { 30.67 C } \\
34.67 \mathrm{~B}\end{array}$ & $\begin{array}{l}24.67 \mathrm{D} \\
25.67 \mathrm{D}\end{array}$ & $\begin{array}{l}16.18 \mathrm{E} \\
16.84 \mathrm{D}\end{array}$ & $\begin{array}{l}16.18 \mathrm{D} \\
16.89 \mathrm{C}\end{array}$ & $\begin{array}{l}4.96 \mathrm{D} \\
5.84 \mathrm{C}\end{array}$ & $\begin{array}{l}\text { 4.00 E } \\
4.33 \mathrm{D}\end{array}$ \\
\hline T4 - 50\% Chemical NPK + compost ( 3 tons) & $37.67 \mathrm{~A}$ & $30.67 \mathrm{C}$ & $17.29 \mathrm{C}$ & $17.56 \mathrm{~B}$ & $6.52 \mathrm{~B}$ & $5.39 \mathrm{C}$ \\
\hline T5 - 50\% Chemical NPK + compost ( 3 tons) + EM & $39.67 \mathrm{~A}$ & 33.67 B & 18.16 A & $18.22 \mathrm{~A}$ & $7.21 \mathrm{~A}$ & $6.14 \mathrm{~B}$ \\
\hline
\end{tabular}

Means followed by the same letter/s within each column didn't significantly differ at $5 \%$ level.

\section{Leaf chemical analysis: \\ Leaf total chlorophyll:}

Table (3) displays obviously that all investigated treatments of using fertilizers resulted significantly in increasing total chlorophyll. However, T1-100\% of chemical NPK and $\mathrm{T}_{5-}-50 \%$ Chemical + compost (3 tons) + EM were statistically superior and showed the highest total chlorophyll levels during the 
2018 \& 2019 seasons, respectively. Other investigated fertilizers treatments could be descendingly arranged about their efficiency as follows: $\mathrm{T} 4-50 \%$ of chemical NPK + compost at the rate 3 tons, T3 - 50\% of chemical NPK + compost at the rate 3 tons and $\mathrm{T} 2$ $-50 \%$ of NPK bio-fertilizations mixture + compost at the rate 2 tons. Besides, the increase in leaf photosynthetic pigments content resulted from the investigated fertilizers treatments may be attributed to the paralleled increase in uptake of $\mathrm{N}$ which plays a vital role in the synthesis of such photosynthetic pigments as an essential constituent of the chlorophyll molecule.

Table 3. Effectiveness of mineral NPK, compost and EM on total chlorophyll, N, and P \% of Washington navel orange trees during $2018 \& 2019$ seasons.

\begin{tabular}{|c|c|c|c|c|c|c|}
\hline \multirow{2}{*}{ Treatments } & \multicolumn{2}{|c|}{ Total Chlorophyll } & \multicolumn{2}{|c|}{$\mathbf{N \%}$} & \multicolumn{2}{|c|}{$\mathbf{P \%}$} \\
\hline & 2018 & 2019 & 2018 & 2019 & 2018 & 2019 \\
\hline T1- Control (100\% chemical). & $11.86 \mathrm{~A}$ & $11.85 \mathrm{~A}$ & $2.85 \mathrm{~A}$ & $2.73 \mathrm{AB}$ & $0.153 \mathrm{AB}$ & $0.153 \mathrm{C}$ \\
\hline T2 - 50\% Chemical NPK + compost ( 2 tons) & 8.99 D & $9.35 \mathrm{D}$ & $2.25 \mathrm{C}$ & $2.36 \mathrm{D}$ & $0.128 \mathrm{C}$ & 0.135 E \\
\hline T3 - 50\% Chemical NPK+ compost ( 2 tons $)+$ & $9.63 \mathrm{D}$ & $9.88 \mathrm{C}$ & $2.44 \mathrm{~B}$ & $2.45 \mathrm{CD}$ & 0.146 B & $0.146 \mathrm{D}$ \\
\hline T4 - 50\% Chemical NPK + compost ( 3 tons) & $10.86 \mathrm{~B}$ & $10.88 \mathrm{~B}$ & $2.54 \mathrm{~B}$ & $2.58 \mathrm{BC}$ & $0.156 \mathrm{~A}$ & 0.162 B \\
\hline T5 - 50\% Chemical NPK + compost ( 3 tons) + & 11.67 A & $11.56 \mathrm{~A}$ & $2.81 \mathrm{~A}$ & $2.74 \mathrm{~A}$ & $0.153 \mathrm{AB}$ & 0.170 A \\
\hline
\end{tabular}

Means followed by the same letter/s within each column didn't significantly differ at 5\% level.

\section{Leaf mineral composition:}

In this regard leaf $\mathrm{N}, \mathrm{P}, \mathrm{K}, \mathrm{Ca}, \mathrm{Mg}, \mathrm{Fe}, \mathrm{Mn}$ and $\mathrm{Zn}$ contents of Washington navel orange trees as influenced by the differential investigated bio and organic fertilizers treatments were the concerned leaf mineral composition as an indicator for nutritional states of tress under study. Data obtained during both 2016 and 2017 experimental seasons are presented in Tables (3), (4) and (5) Tabulated data revealed that the investigated treatment representative with chemical fertilizers $(100 \%)$ resulted significantly in increasing Leaf mineral composition of Washington navel orange trees as compared to the other investigated treatments. On the other side, compost only at different rates $\left(2^{\text {nd }} \& 4^{\text {th }}\right.$ treatments $)$ didn't affect leaf mineral composition. Such a trend was actual during both the 2018\& 2019 experimental seasons.

Table 4. Effectiveness of mineral NPK, compost and EM on $\mathrm{K}, \mathrm{Mg}$, and $\mathrm{Ca} \%$ of Washington navel orange trees during 2018 \& 2019 seasons.

\begin{tabular}{lcccccr}
\hline \multirow{2}{*}{ Parameters } & \multicolumn{2}{c}{ K\% } & \multicolumn{2}{c}{ Mg\% } & \multicolumn{2}{c}{ Ca\% } \\
\cline { 2 - 7 } Treatments & $\mathbf{2 0 1 8}$ & $\mathbf{2 0 1 9}$ & $\mathbf{2 0 1 8}$ & $\mathbf{2 0 1 9}$ & $\mathbf{2 0 1 8}$ & $\mathbf{2 0 1 9}$ \\
\hline T1- Control (100\% chemical). & $1.85 \mathrm{~A}$ & $1.90 \mathrm{~A}$ & $0.553 \mathrm{AB}$ & $0.570 \mathrm{AB}$ & $4.23 \mathrm{C}$ & $4.23 \mathrm{~A}$ \\
T2 - 50\% Chemical NPK + compost ( 2 tons) & $1.47 \mathrm{C}$ & $1.58 \mathrm{E}$ & $0.466 \mathrm{C}$ & $0.480 \mathrm{C}$ & $4.17 \mathrm{C}$ & $4.04 \mathrm{C}$ \\
T3 - 50\% Chemical NPK+ compost ( 2 tons) + EM & $1.57 \mathrm{~B}$ & $1.68 \mathrm{D}$ & $0.520 \mathrm{~B}$ & $0.523 \mathrm{BC}$ & $4.27 \mathrm{C}$ & $4.10 \mathrm{BC}$ \\
T4 - 50\% Chemical NPK + compost ( 3 tons) & $1.62 \mathrm{~B}$ & $1.75 \mathrm{C}$ & $0.583 \mathrm{~A}$ & $0.580 \mathrm{~A}$ & $4.39 \mathrm{~B}$ & $4.18 \mathrm{AB}$ \\
T5 - 50\% Chemical NPK + compost ( 3 tons) + EM & $1.78 \mathrm{~A}$ & $1.83 \mathrm{~B}$ & $0.550 \mathrm{AB}$ & $0.550 \mathrm{AB}$ & $4.57 \mathrm{~A}$ & $4.19 \mathrm{AB}$ \\
\hline
\end{tabular}

Means followed by the same letter/s within each column didn't significantly differ at $5 \%$ level.

Table 5. Effectiveness of mineral NPK, compost and EM on Fe, Mn and Zn (ppm) contents of Washington navel orange trees during 2018 \& 2019 seasons.

\begin{tabular}{|c|c|c|c|c|c|c|}
\hline \multirow[b]{2}{*}{ Treatments } & \multicolumn{2}{|c|}{ Fe (ppm) } & \multicolumn{2}{|c|}{ Mn (ppm) } & \multicolumn{2}{|c|}{ Zn (ppm) } \\
\hline & 2018 & 2019 & 2018 & 2019 & 2018 & 2019 \\
\hline T1- Control (100\% chemical). & 81.03 A & $79.21 \mathrm{~A}$ & $45.67 \mathrm{~A}$ & $44.28 \mathrm{~A}$ & $37.08 \mathrm{~A}$ & $35.61 \mathrm{~A}$ \\
\hline T2 - 50\% Chemical NPK + compost ( 2 tons) & $66.79 \mathrm{E}$ & $70.85 \mathrm{D}$ & 37.15 D & $39.95 \mathrm{D}$ & $30.17 \mathrm{E}$ & $30.49 \mathrm{D}$ \\
\hline T3 - 50\% Chemical NPK+ compost ( 2 tons $)+$ EM & $70.45 \mathrm{D}$ & $72.41 \mathrm{CD}$ & 40.77 C & 41.61 C & $32.20 \mathrm{D}$ & 32.01 C \\
\hline T4 - 50\% Chemical NPK + compost ( 3 tons) & 74.44 C & $73.68 \mathrm{C}$ & 41.76 BC & $42.82 \mathrm{~B}$ & $34.04 \mathrm{C}$ & $33.62 \mathrm{~B}$ \\
\hline T5 - 50\% Chemical NPK + compost ( 3 tons) + EM & 78.46 B & $76.58 \mathrm{~B}$ & $42.39 \mathrm{~B}$ & $42.99 \mathrm{~B}$ & 36.16 B & $34.99 \mathrm{~A}$ \\
\hline
\end{tabular}

Means followed by the same letter/s within each column didn’t significantly differ at 5\% level.

However, T1-100\% of chemical NPK and T5$50 \%$ of chemical NPK + EM were statistically superior whereas the difference was so slight and could be safely neglected between the two treatments. Moreover, T4 - 50\% of chemical NPK + compost at the rate 3 tons ranked statistically $2^{\text {nd }}$, while $\mathrm{T} 3-50 \%$ of chemical NPK + compost at the rate 2 tons + EM came third. Such a trend was actual during both the 2018 \& 2019 experimental seasons. 


\section{Fruiting measurements:}

In this regard percentage of both (fruits set \& retention), tree productivity (yield) and fruit quality (physical \& chemical properties) were the investigated fruiting parameters for Washington navel orange trees pertaining their response to the differential studied treatments.

\section{Fruits set \& retention \%:}

Table (6) displays obviously that four investigated treatments increased the fruits set \& retention \% over T2 - 50\% of chemical NPK + compost at the rate of 2 tons significantly. However, T1-100\% of chemical NPK and T5- 50\% of chemical $\mathrm{NPK}+$ compost at the rate 3 tons + EM were statistically superior in this concern during both the $2018 \& 2019$ experimental seasons. However, the $4^{\text {th }}$ treatment $(50 \%$ of chemical NPK + compost at the rate 3 tons) ranked statistically second, descendingly followed by T3 - 50\% of chemical NPK + compost at the rate 2 tons + EM during two experimental seasons.

Table 6. Effectiveness of mineral NPK, compost and EM on fruit set (\%), fruit retention (\%) and fruit drop (\%) of Washington navel orange trees during 2018 \& 2019 seasons.

\begin{tabular}{|c|c|c|c|c|c|c|}
\hline \multirow{2}{*}{ Treatments } & \multicolumn{2}{|c|}{ Fruit set \% } & \multicolumn{2}{|c|}{ Fruit retention $\%$} & \multicolumn{2}{|c|}{ Fruit drop \% } \\
\hline & 2018 & 2019 & 2018 & 2019 & 2018 & 2019 \\
\hline T1- Control (100\% chemical). & $19.92 \mathrm{~A}$ & $19.23 \mathrm{~A}$ & $14.62 \mathrm{~A}$ & $14.31 \mathrm{~A}$ & $85.69 \mathrm{E}$ & $85.69 \mathrm{E}$ \\
\hline T2 $-50 \%$ Chemical NPK + compost ( 2 tons) & $15.99 \mathrm{E}$ & $15.91 \mathrm{E}$ & $11.38 \mathrm{E}$ & 11.137 E & $88.62 \mathrm{~A}$ & $88.86 \mathrm{~A}$ \\
\hline T3 - 50\% Chemical NPK + compost ( 2 tons) + EM & 17.11 D & 16.72 D & $11.93 \mathrm{D}$ & 11.917 D & 88.07 D & 88.08 D \\
\hline T4 - 50\% Chemical NPK + compost ( 3 tons) & $17.79 \mathrm{C}$ & $17.76 \mathrm{C}$ & $12.51 \mathrm{C}$ & 12.633 C & 87.49 C & 87.37 C \\
\hline T5 - 50\% Chemical NPK + compost ( 3 tons) + EM & $18.62 \mathrm{~B}$ & $18.70 \mathrm{~B}$ & $13.66 \mathrm{~B}$ & $13.92 \mathrm{~B}$ & 86.34 B & 86.08 B \\
\hline
\end{tabular}

Means followed by the same letter/s within each column didn't significantly differ at $5 \%$ level.

This result may be attributed to the relatively higher uptake of more accessible $\mathrm{N}$ form that could be absorbed and/or trans located within tissues as a direct result of applying such $\mathrm{N}$ more productive compounds where an adequate and sufficient $\mathrm{N}$ level is needed at such a critical stage of flower - fruit development.

On the other side, all investigated chemical, organic and bio nutritive fertilizers treatments resulted significantly in reducing fruit drop $\%$ as compared to $\mathrm{T}_{2}(50 \%$ of chemical NPK + compost at the rate 2 tons). The most effective treatment to decrease fruit drop percent was in close partnership with the Washington navel orange trees. subjected to T1-100\% of chemical NPK and T5- 50\% of chemical NPK + compost at the rate 3 tons + EM during both 2018 \& 2019 experimental seasons. Whereas the highest reduction in fruit drop \% was exhibited.

\section{Tree productivity (yield):}

The yield of the Washington navel orange cv. expressed either as number or weight $(\mathrm{kg})$ of fruit harvested per flower, two productivity parameters for reaction to differential assessed treatments were investigated. The data collected during the seasons are shown in Table (7). Herein, the cropping parameters of tree productivity followed the same trend, whereas T1-100\% of chemical NPK and T5- 50\% of chemical $\mathrm{NPK}+$ compost at the rate 3 tons + EM surpassed all other treatments statistically during both seasons of study. However, T4 - 50\% of chemical NPK + compost at the rate of 3 ton ranked statistically second. On the contrary, T2 - 50\% of chemical NPK + compost at the rate of 2 tons ranked statically last in this regard during both seasons of study.

Table 7. Effectiveness of mineral NPK, compost and EM on average fruit weight, number of fruits/tree, yield/tree $(\mathrm{Kg})$ and yield /Fedan (Ton) of Washington navel orange trees during 2018 and 2019 experimental seasons.

\begin{tabular}{|c|c|c|c|c|c|c|c|c|}
\hline \multirow[t]{2}{*}{ Treatments } & \multicolumn{2}{|c|}{$\begin{array}{c}\text { Average fruit } \\
\text { weight }\end{array}$} & \multicolumn{2}{|c|}{ No. of fruits/tree } & \multicolumn{2}{|c|}{ Yield/tree (Kg) } & \multicolumn{2}{|c|}{$\begin{array}{c}\text { Yiled } \\
\text { /Feddan(Ton) }\end{array}$} \\
\hline & 2018 & 2019 & 2018 & 2019 & 2018 & 2019 & 2018 & 2019 \\
\hline T1- Control (100\% chemical). & $280.67 \mathrm{~A}$ & $280.83 \mathrm{~A}$ & $163.33 \mathrm{~A}$ & $161.33 \mathrm{~A}$ & $45.87 \mathrm{~A}$ & $45.33 \mathrm{~A}$ & $7.71 \mathrm{~A}$ & $7.62 \mathrm{~A}$ \\
\hline T2 - 50\% Chemical NPK + compost ( 2 tons) & 261.03 E & 255.67 C & 124.33 D & 124.33 D & 32.48 D & $31.80 \mathrm{D}$ & $5.46 \mathrm{D}$ & $5.34 \mathrm{D}$ \\
\hline T3 - 50\% Chemical NPK+ compost ( 2 tons ) + EM & 265.63 D & $264.33 \mathrm{C}$ & 139.67 C & 141.00 C & $37.12 \mathrm{C}$ & $37.31 \mathrm{C}$ & $6.24 \mathrm{C}$ & $6.24 \mathrm{C}$ \\
\hline T4 - 50\% Chemical NPK + compost ( 3 tons) & 273.33 C & $275.83 \mathrm{~A}$ & $152.00 \mathrm{~B}$ & $150.33 \mathrm{~B}$ & $41.56 \mathrm{~B}$ & $41.48 \mathrm{~B}$ & $6.99 \mathrm{~B}$ & $6.97 \mathrm{~B}$ \\
\hline T5 - 50\% Chemical NPK + compost ( 3 tons) + EM & $276.33 \mathrm{~B}$ & $275.67 \mathrm{~B}$ & 159.33 AB & 159.33 A & 44.01 A & $43.93 \mathrm{~A}$ & $7.39 \mathrm{~A}$ & $7.38 \mathrm{~A}$ \\
\hline
\end{tabular}

Means followed by the same letter/s within each column didn't significantly differ at $5 \%$ level.

\section{Fruit quality:}

Fruit physical properties:

In this regard, fruit dimensions (equatorial \& polar diameters), fruit shape index, peel thickness and juice $\%$ and weight were the evaluated fruit physical properties of Washington navel orange $\mathrm{Cv}$. in response to the differential investigated fertilizers treatments. Data obtained during both the 2018 \& 2019experimental seasons are presented in Tables $(8$ and 9).

As shown from Tables (8 and 9) the fruit physical properties of Washington navel orange $\mathrm{cv}$. were increased significantly by applying any of the investigated fertilizers treatments as compared to $T_{2}$ - 
$50 \%$ chemical NPK + compost at the rate of 2 tons during both experimental seasons. However, the greatest increase was statistically detected by both $\mathrm{T} 1$ and $\mathrm{T}_{5}$ i.e., (100\% chemical NPK) and (50\% chemical $\mathrm{NPK}+$ compost at the rate 3 tons $+\mathrm{EM}$ ) both effective treatments showed approximately the same values of different fruit physical properties. Moreover, $\mathrm{T}_{4}-50 \%$ chemical NPK + compost at the rate 3 tons ranked statistically second, followed by T3-50 \% chemical $\mathrm{NPK}+$ compost at a rate of 2 tons $+\mathrm{EM}$. This pattern was valid in both experiment seasons with few exceptions, particularly with the fruit shape index. Fruit shape index (polar diameter: equatorial diameter) of the Washington navel orange cv. In addition, to unequal care under review, Table (8) indicates that the variances were relatively too few to take into account from a statistical point of view. Variations in fruit shape indices attributable to the differential inspected fertilization treatments could theoretically be clarified by the unprecedented reaction of two fruit sizes (polar and equatorial diameters) to the given treatment. In most cases, the increase in fruit length (height or polar diameter) was comparatively higher than the increase in fruit width (equatorial diameter) as the response to each treatment was taken independently (separately) into account.

Table 8. Effectiveness of mineral NPK, compost and EM on polar diameter $(\mathrm{cm})$, equatorial diameter $(\mathrm{cm})$ and fruit shape index of Washington navel orange trees during 2018 \& 2019 seasons.

\begin{tabular}{|c|c|c|c|c|c|c|}
\hline \multirow[t]{2}{*}{$\begin{array}{l}\text { Treatments } \\
\text { Parameters }\end{array}$} & \multicolumn{2}{|c|}{$\begin{array}{c}\text { Polar diameter } \\
(\mathrm{cm})\end{array}$} & \multicolumn{2}{|c|}{$\begin{array}{c}\text { Equatorial } \\
\text { diameter } \\
(\mathrm{cm})\end{array}$} & \multicolumn{2}{|c|}{ Fruit shape index } \\
\hline & 2018 & 2019 & 2018 & 2019 & 2018 & 2019 \\
\hline T1- Control (100\% chemical). & $8.38 \mathrm{~A}$ & $8.39 \mathrm{~A}$ & $8.46 \mathrm{~A}$ & $8.43 \mathrm{~A}$ & 0.991 B & 0.996 B \\
\hline T2 - 50\% Chemical NPK + compost ( 2 tons) & $7.90 \mathrm{C}$ & $7.90 \mathrm{D}$ & $7.56 \mathrm{D}$ & $7.88 \mathrm{C}$ & $1.006 \mathrm{~A}$ & $1.002 \mathrm{~A}$ \\
\hline T3 $-50 \%$ Chemical NPK+ compost ( 2 tons) + & 7.95 & & & & 0.998 & \\
\hline EM & BC & 7.96 CD & $7.97 \mathrm{C}$ & $7.99 \mathrm{~B}$ & $\mathbf{A B}$ & 0.997 AB \\
\hline $\begin{array}{l}\text { T4 - 50\% Chemical NPK }+ \text { compost }(3 \text { tons }) \\
\text { T5 - 50\% Chemical NPK }+ \text { compost }(3 \text { tons })+\end{array}$ & 8.03 B & 8.01 BC & 8.06 B & 8.04 B & $\begin{array}{c}0.996 \text { B } \\
0.997\end{array}$ & $0.996 \mathrm{~B}$ \\
\hline EM & $8.04 \mathrm{~B}$ & 8.06 B & 8.067 B & 8.05 B & AB & $1.001 \mathrm{AB}$ \\
\hline
\end{tabular}

Means followed by the same letter/s within each column didn't significantly differ at $5 \%$ level.

Table 9. Effectiveness of mineral NPK, compost and EM on peel thickness (mm), juice \% and juice weight of Washington navel orange trees during 2018 \& 2019 seasons.

\begin{tabular}{|c|c|c|c|c|c|c|}
\hline \multirow[t]{2}{*}{ Treatments } & \multicolumn{2}{|c|}{$\begin{array}{l}\text { Peel thickness } \\
(\mathbf{m m})\end{array}$} & \multicolumn{2}{|c|}{ Juice \% } & \multicolumn{2}{|c|}{ Juice weight } \\
\hline & 2018 & 2019 & 2018 & 2019 & 2018 & 2019 \\
\hline T1- Control (100\% chemical). & $3.13 \mathrm{~A}$ & $3.12 \mathrm{~A}$ & $44.45 \mathrm{~A}$ & $43.64 \mathrm{~A}$ & $124.76 \mathrm{~A}$ & $122.56 \mathrm{~A}$ \\
\hline T2 - 50\% Chemical NPK + compost ( 2 tons) & 2.81 D & $2.75 \mathrm{E}$ & 39.76 D & 40.38 D & 103.81 E & 103.25 E \\
\hline T3 - 50\% Chemical NPK+ compost ( 2 tons) + EM & $2.95 \mathrm{C}$ & $2.92 \mathrm{D}$ & $41.92 \mathrm{C}$ & $41.56 \mathrm{C}$ & 111.36 D & 109.87 D \\
\hline T4 - 50\% Chemical NPK + compost ( 3 tons) & $3.02 \mathrm{~B}$ & $2.99 \mathrm{C}$ & 43.23 B & 42.71 B & 118.16 C & 117.83 C \\
\hline T5 - 50\% Chemical NPK + compost ( 3 tons) + EM & 3.00 B & 3.03 B & 44.21 A & 43.59 A & $122.06 \mathrm{~B}$ & $120.17 \mathrm{~B}$ \\
\hline
\end{tabular}

Means followed by the same letter/s within each column didn't significantly differ at $5 \%$ level.

\section{Fruit chemical characteristics:}

In this regard, fruit juice total soluble solids (TSS) \%, total acidity \%, TSS / acid ratio, total sugars $\%$ and ascorbic acid (vitamin C) contents were the five investigated fruit juice chemical properties for Washington navel orange $\mathrm{cv}$. regarding their response to the differential treatments. Data obtained during both the 2018 \& 2019 experimental seasons are presented in Tables (10 and 11). Herein, it is quite clear that the response of fruit juice chemical properties for Washington navel orange cv. to the differential investigated treatments followed to great extent the same trend previously detected with fruit physical properties. However, the differences were relatively more firm with fruit physical properties. Hence, $\mathrm{T}_{1}$ and $\mathrm{T}_{5}$ i.e., (100\% chemical NPK) and (50\% chemical NPK + compost at the rate 3 tons +
EM), respectively were statistically the most effective and showed significantly the same level fruit juice chemical properties for Washington navel orange cv. during both experimental seasons. Moreover, $\mathrm{T}_{4}(50 \%$ chemical NPK + compost at the rate of 3 tons) ranked statistically second as the influence on fruit juice chemical properties were concerned. The reverse was true with $\mathrm{T}_{2}-50 \%$ chemical NPK + compost at the rate of 2 tons that induced significantly the poorest fruits in their fruit juice chemical properties during both seasons. Besides, other investigated treatments were in between the abovementioned two extremes. Such a trend was true during both seasons of study with little exceptions especially with the TSS / acid ratio, which was slightly influenced by the differential investigated treatments. 
Table 10. Effectiveness of mineral NPK, compost and EM on T.S.S \%, total acidity \% and TSS/Acid ratio of Washington navel orange trees during 2018 \& 2019 seasons.

\begin{tabular}{|c|c|c|c|c|c|c|}
\hline \multirow{2}{*}{$\begin{array}{l}\text { Treatments } \\
\text { Parameters }\end{array}$} & \multicolumn{2}{|c|}{ T.S.S (\%) } & \multicolumn{2}{|c|}{ Total acidity (\%) } & \multicolumn{2}{|c|}{ TSS/Acid ratio } \\
\hline & 2018 & 2019 & 2018 & 2019 & 2018 & 2019 \\
\hline T1- Control (100\% chemical). & $11.87 \mathrm{~A}$ & $11.98 \mathrm{~A}$ & $1.046 \mathrm{~A}$ & $1.042 \mathrm{~A}$ & $\mathbf{1 1 . 3 4 ~ B ~}$ & $11.459 \mathrm{AB}$ \\
\hline T2 - 50\% Chemical NPK + compost ( 2 tons) & $10.34 \mathrm{E}$ & 10.57 D & $1.003 \mathrm{~B}$ & $1.006 \mathrm{~A}$ & 101.31 D & $10.51 \mathrm{~B}$ \\
\hline T3 - 50\% Chemical NPK + compost ( 2 tons) + EM & $10.84 \mathrm{D}$ & 11.01 CD & 0.997 B & $1.002 \mathrm{AB}$ & $10.87 \mathrm{C}$ & $10.99 \mathrm{~B}$ \\
\hline T4 - 50\% Chemical NPK + compost ( 3 tons) & 11.12 C & 11.23 BC & $0.981 \mathrm{C}$ & 0.986 AB & 11.34 B & $11.39 \mathrm{~B}$ \\
\hline T5 - 50\% Chemical NPK + compost ( 3 tons) + EM & $11.56 \mathrm{~B}$ & $11.59 \mathrm{AB}$ & $0.993 \mathrm{BC}$ & 0.924 B & 11.64 A & $12.56 \mathrm{~A}$ \\
\hline
\end{tabular}

Means followed by the same letter/s within each column didn't significantly differ at $5 \%$ level.

Table 11. Effectiveness of mineral NPK, compost and EM on total sugars (\%) and vitamin C of Washington navel orange trees during 2018 \& 2019 seasons.

\begin{tabular}{|c|c|c|c|c|}
\hline \multirow{2}{*}{ Parameters } & \multicolumn{2}{|c|}{ Total sugars (\%) } & \multicolumn{2}{|c|}{ V.C (mg/100 ml juice) } \\
\hline & 2018 & 2019 & 2018 & 2019 \\
\hline T1- Control (100\% chemical). & $8.66 \mathrm{~A}$ & $8.53 \mathrm{~A}$ & $61.25 \mathrm{~A}$ & $60.07 \mathrm{~A}$ \\
\hline T2 $-50 \%$ Chemical NPK + compost $(2$ tons) & $7.96 \mathrm{D}$ & $7.73 \mathrm{D}$ & $55.25 \mathrm{E}$ & $54.74 \mathrm{E}$ \\
\hline T3 - 50\% Chemical NPK+ compost ( 2 tons) + EM & 8.13 C & 8.04 C & $56.92 \mathrm{D}$ & 55.97 D \\
\hline T4 - 50\% Chemical NPK + compost ( 3 tons) & $8.41 \mathrm{~B}$ & $8.32 \mathrm{~B}$ & $58.25 \mathrm{C}$ & $56.80 \mathrm{C}$ \\
\hline T5 - 50\% Chemical NPK + compost ( 3 tons) + EM & $8.55 \mathrm{AB}$ & $8.57 \mathrm{~A}$ & 59.39 B & 57.92 B \\
\hline
\end{tabular}

Means followed by the same letter/s within each column didn't significantly differ at $5 \%$ level.

\section{Discussion}

Continuous use of chemical fertilization contributes to the degradation of soil characteristics and fertility and deposition of heavy metals in plant tissues, affecting the nutritional value and edibility of the fruit. (Tamara et al., 2005). There is a general agreement that nutrition is one of the most effective factors affecting tree growth, yield, and fruit quality, (Kassem and Marzouk, 2002), however, the high cost of mineral fertilization is a major problem affecting fruit tree growers. In addition, a new study has shown that mineral fertilizers have a role to play in health issues and environmental degradation. Besides, agricultural land is impoverished and high doses of agrochemicals need to be introduced, which greatly pollute the environment in the long run. To make agriculture sustainable; the balanced and conscientious use of organic farming and other natural resources available (Kabeel $\boldsymbol{e t}$ al., 2005).

Organic fertilization improves the physical, chemical and biological properties of all soil forms, changes soil $\mathrm{pH}$, increases soil solubility and plant output. Adding organic fertilizers not only increases the organic matter in the soil but also increases the available phosphorus and the exchangeable potassium, calcium and other micro-elements by affecting soil $\mathrm{pH}$, Promotes the propagation of soil microorganisms, raises the microbial community and the activity of microbial enzymes. (Abou-Hussein $\boldsymbol{e t}$ al., 2002).

Bio-fertilizers are one of the most significant factors for plant development and soil productivity as they play an important role in growing the vegetative growth, yield and fruit quality of citrus trees. (Abdelaal et al., 2013, El-Khawaga and Maklad, 2013 and El-Khayat and Abdel Rehiem, 2013).

Bio-fertilizers are simple and effective to manage on-the-ground applications and are very safe for humans, livestock and the atmosphere to increase their productivity by raising crop yields and lowering the costs of certain farming activities. It does not substitute mineral fertilizers but greatly reduce their application rate. (Ishac, 1989 and Saber, 1993).

The basic goal of EM is to restore a balanced environment in both soil and water by using the genus of microorganisms present in nature. Generally, EM technology has been implemented internationally and is known as a versatile and successful method in agriculture and horticulture for crop and animal production systems. (Chamberlain et al., 1997). EM is used to enhance soil fertility and organic farming conditions. (Higa, 1991 and Higa and Wididana, 1991).

Our findings are supported by the results obtained by Mansour and Shaaban (2007) and Sharaf et al., (2011) on Washington Navel Orange Trees, Osman, et al., (2011) on Bartamuda date, palm, Barakat et al., (2012) on Newhall naval orange, Zaghloul and Knany, (2012) on Navel orange, PeraltaAntonio et al., (2014) on mango, Salama et al., (2014) on "Hayany" Date Palm, Baiea, et al., (2015) on banana cv. Grande Naine, Baiea and EL-Gioushy (2015) on banana cv. Grande Naine, EL-Gioushy and Baiea (2015) on apricot, EL-Gioushy (2016) on Manfalouty pomegranate trees, Mostafa et al., (2016) on Washington navel orange, El-Badawy, (2017) on Valencia orange, Samra et al. (2017) on Washington Navel Orange, El-Badawy et al., (2017) on Washington Navel Orange Trees, Baiea et al., (2017) on Wonderful pomegranate trees, El-Gioushy et al., (2018) on Fagri Kalan Mango trees, El-Gioushy and Eissa (2019) on Washington Navel Orange and Fikry et al., (2020) on Murcott Tangerine Trees. 


\section{Conclusion}

It can be recommended that minimizing 50 $\%$ chemical NPK fertilizers by compost at the rate of 3 tons/fed $+\mathrm{EM}$ at the rate of $20 \mathrm{ml} /$ tree enhanced vegetative growth, leaf chemical contents, productivity and fruit quality of Washington navel orange trees which associated with lower production cost under the same conditions.

\section{References}

Abdelaal, A.H.; Ahmed, F.F.; El-Masry, S.E. and Abdallah, A.A. (2013). Using potassium sulphur as well as organic and bio fertilization for alleviating the adverse effects of salinity on growth and fruiting of Valencia orange trees. Stem Cell 4(4):27-32.

Abdelaal, S. H.; Mohamed, E. and Kabeil, S.S. (2010). Microbial bio-fertilization approaches to Improve yield and quality of Washington navel orange and reducing the survival of nematode in the soil. J. American Sci., 6(12): 264-272.

Abd-Rabou, F.A. (2006). Effect of Microbien, Phosphoreneand effective micro-organisms (EM) as bio-stimulants on growth of avocado and mango seedlings. Egyptian J.Applied Sci., 21(6B): 673693.

Abobatta W. (2018). Improving navel orange (Citrus sinensis L) productivity in Delta Region, Egypt. Adv. Agr. Environ Sci. (2018); 2(1): 8-10.

Abou-Hussein, S. D.; El-Oksha, I.; El-Shorbagy, T. and Gomaa, A. M. (2002). Effect of cattle manure, biofertilizers and reducing mineral fertilizer on nutrient content and yield of Potato plant. Egypt. J. Hort., 29 (1): 99-115.

Association of Official Agriculture Chemists (A.O.A.C.) (1995). Official Methods of Analysis pub. By A.O.A.C. Chap. (45) 18-20, (37)10, Virginia 22201-3301. U.S.A.

Annual Reports of Statistical Institute and Agricultural Economic Research in Egypt.

2016.

Baiea, M. H. M.; Abdel Gawad-Nehad, M. A. and Abedelkhalek, A. (2017). Influence of natural alternative NPK and biofertilizations on vegetative growth and nutritional status of young Wonderful pomegranate trees. Asian Journal of Soil Science and Plant Nutrition. 2(3): 1-8.

Baiea, M.H.M., and EL-Gioushy, S. F.(2015). Effect of some different sources of organic fertilizers in presence of bio-fertilizer on growth and yield of banana cv. Grande Naine plants. Middle East Journal of Agriculture Research. 4(4): 745-753. 2015.

Baiea, M.H.M.; EL-Gioushy, S. F. and El-Sharony, T. F. (2015). Effect of feldspar and biofertilization on growth, productivity and fruit quality of banana cv. Grande Naine. International Journal of Environment. 4(4): 210-218.
Barakat, M.R.; Yehia T.A. and Sayed, B.M. (2012). Response of Newhall naval orange to bio-organic fertilization under newly reclaimed area conditions i: vegetative growth and nutritional status. Journal of Horticultural Science \& Ornamental Plants 4 (1): 18-25.

Black, C.A.; Evans, D.O.; Ensminger, L.E.; White, J.L.; Clark, F.E. and Dinauer, R.C. (1982). Methods of soil analysis. Part 2. Chemical and microbiological properties. 2nd Ed. Soil Sci., Soc. of Am. Inc. Publ., Madison, Wisconsin, U. S.A.

Brown, J.D. and Lilliand, O. (1946). Rapid determination of potassium and sodium in plant material and soil extract by flame photometer. Proc. Amer. Soc. Hort. Sci., 48: 341-346.

Chamberlain, T.P.; Daly, M.J. and Merfield, C.N., (1997). Utilization of Effective Microorganisms in commercial organic agriculture: A Case Study from New Zealand. Proc. 5th InternationalKyusei Nature Farming Conference, pp: 120-123. Bangkok, Thailand.

Chapman, H. D., and Pratt, P. F., (1961). Methods of Analysis for Soil, Plant and Waters. Univ. of Calif. Division of Agric. Sc. $6^{\text {th }}$ Ed. P: 56-64.

Duncan, D. B. (1955). Multiple ranges and multiple F. test. Biometrics,

El-Badawy, H. E. M.; El-Gioushy S. F.; Baiea M. H. M. and EL-Khwaga, A. A. (2017). Effect of some antioxidants and nutrients treatments on vegetative growth and nutritional status of Washington navel orange trees. Middle East Journal of Agriculture Research .6(1): 87-98.

El-Badawy, H.E.M. (2017). Partial substitution of Valencia orange chemical fertilization by bioorganic fertilization conjoint with algae extract foliar spray. Middle East Journal of Applied Sciences, 7(4): pp, 1016-1030.

EL-Gioushy, S. F. and Baiea, M. H. M. (2015). Partial substitution of chemical fertilization of Canino apricot by bio and organic fertilization. Middle East Journal of Applied Sciences. 5(4): 823-832.

El-Gioushy, S.F. and Eissa, A. M. (2019). Effectiveness of different NPK fertilization sources on growth, nutritional status, productivity and fruit quality of Washington navel orange trees. J. of Hort. Sci. \& Ornam. Plants 11 (2): 134-143, 2019.

El-Gioushy, S.F., (2016). Comparative study on the NPK fertilization sources of young Manfalouty pomegranate trees. J. Plant Production, Mansoura Univ., 7(10): 1037-1042.

El-Gioushy, S.F.; Abedelkhalek, A. and Abdelaziz, A.M.R.A. (2018). Partial replacement of mineral NPK by organic and bio-fertilizers of Fagri Kalan mango trees. Journal of Horticultural Science \& Ornamental Plants, 10(3): 110-117.

El-Khawaga, A.S. and. Maklad, M.F. ( 2013). Effect of combination between bio and chemical fertilization on vegetative growth, yield and 
quality of Valencia orange fruits. HortScience Journal of Suez Canal University, 1: 269-279.

El-Khayat, H.M. and Abdel-Rehiem, M.A. (2013). Improving mandarin productivity and quality by using mineral and bio-fertilization. Alex. J. Agric. Res. 58(2): $141-147$.

Fikry, A. M.; Abou Sayed-Ahmed T.A.M.; Mohsen, F.S. and Ibrahim, M.M. (2020). Effect of nitrogen fertilization through inorganic, organic and biofertilizers sources on vegetative growth, yield and nutritional status in Marcott tangerine trees. Plant Archives Volume 20 No. 1, pp. 18591868.

Higa, T. (2010). Effective microorganisms as a commercial product. http://econature.wordpress.com/2010/04/15/effect ivemicroorganisms-em.

Higa, T. and Wididana, G.N. (1991). The concept and theories of Effective Microorganisms. In: Parr, J.F., S.B. Hornick and C.E. Whitman (eds.), Proc. First International Conference on Kyusei Nature Farming, US Department of Agriculture, Washington, D.C., pp: 118-124.

Higa, T., (1986). Studies on the application of effective microorganisms in natural farming. 6th IFOAM Conference, Aug. 18-21, 1986, California University.

Higa, T., (1991). Effective microorganisms: A biotechnology for mankind. In: Parr, J.F., S.B. Hornick and C.E. Whitman (eds.), Proc First International Conference on Kyusei Nature Farming, pp: 8-14. U.S. Department of Agriculture, Washington, DC

Ishac, Y. Z. (1989). Inoculation with associative N2fixers Egypt. Nitrogen fixation with non-legumes, Kluwer Academic Publishers. Pp. 241-246.

Kabeel, H.; Abd EL-Latif, G. S. and Khalil, A. A. (2005). Effect of soil application of different mineral and biofertilizer treatments on growth, fruiting parameters, fruit properties and leaf nutrient content of "Canino" apricot trees. J. Agric. Sci. Mansoura Univ., 30(3): 1583-1594.

Kassem, H. A. and Marzouk, H. A. (2002). Effect of organic and/or mineral nitrogen fertilization on the nutritional status, yield, and fruit quality of Flame seedless grapevines grown in calcareous soils. J. Advan. Agric. Res., 7 (1): 118-126.

Loredana, L.; Catello, P.; Donatella, A.; Giuseppe, C.; Massimo, Z. and Mrisa, D. (2015). Compost and compost tea management of mini watermelon cultivations affects the chemical, physical and sensory assessment of the fruits. Agricultural Sciences, 6,117-125.

Mansour, A.E.M. and Shaaban, E.A. (2007). Effect of different sources of mineral $\mathrm{N}$ applied with organic and biofertilizers on fruiting of Washington navel orange trees. Journal of Applied Sciences Research, 3(8): 764-769.

Ministry of Agriculture and Land Reclamation, (2015). Agricultural statistics, Egypt.
Mostafa, M. F. M.; El-Boray, M.S.S.; Shalan, A.M. N. and Ghaffar, A. H. (2016). Effect of magnetized irrigation water levels and compost on vegetative growth, leaf mineral content and water use efficiency of Washington navel orange trees. J. Plant Production, Mansoura Univ., Vol. 7 (2): $249-255$.

Osman, S. O.A.; Moustafa, F. M. A.; Abd El-Galil, H. A. and Ahmed, A.Y.M. (2011). Effect of yeast and effective microorganisms (EM1) application on the yield and fruit characteristics of Bartamuda date palm under Aswan conditions. Assiut J. of Agric. Sci., 42 (Special Issue) (The 5th Conference of Young Scientists Fac. of Agric. Assiut Univ. May 8, 2011) (332-349).

Paschoal, A.D.; Senanayakc, Y.D.A. and Sangak Kara, U.R. (1999). Improved soil chemical and physical conditions and their relations to yield and fruit quality of orange in afield under Kyusei Nature Farming and EM. Technology in Brazil. Fifth International Conference on Kyusei Nature.

Peralta-Antonio, N.; Rebolledo-Martínez, A.; Becerril-Román, A.; Jaén-Contreras, E. D. and del Angel-Pérez, A. L., (2014). Response to organic fertilization in mango cultivars: Manila, Tommy Atkins and Ataulfo. J. Soil Sci. Plant Nutr. 14, 688-700.

Piper, C. S. (1958). Soil and Plant Analysis. Inter. Sci. Publishers. New York, 213-217.

Pregl, E. (1945). Quantitative Organic Micro Analysis. $4^{\text {th }}$ Ed. Chundril, London.

Saber, S. M. (1993). The use of multi-strain biofertilizer in agriculture. Theory and practice. Proc. Sixth International Symposium on Nitrogen Fixation with Non-legumes, Ismailia, Egypt, p.61.

Salama, A. S.M.; El- Sayed, O. M. and El Gammal, O. H.M. (2014). Effect of effective microorganisms (EM) and potassium sulphate on productivity and fruit quality of "Hayany" date palm grown under salinity stress. IOSR Journal of Agriculture and Veterinary Science. 7 (6): Ver. I, PP 90-99.

Samra, N. R.; EL-Kady, M. I.; Hikal, A. R. and Ghanem, M. S. H. (2017). Effect of organic fertilization on fruit Set, dropping, yield and fruit quality of Washington navel orange. J. Plant Production, Mansoura Univ., Vol. 8 (8): 853 858.

Sharaf, M.M.; Bakry, Kh. A. and EL- Gioushy, S. F. (2011). The influence of some bio and organic nutritive addenda on growth, productivity, fruit quality and nutritional status of Washington navel orange trees. Egypt.J. of Appl.Sci. 26(9) 253- 268.

Shiralipour, A.; McConnell, D. and W. Smith, (1992).Physical and chemical properties of soils as affected by municipal solid waste compost application.Biomass and Bioenergy, 3: 261-266.

Smith F, Cilles AM, Hamilton KJ, Gedes AP. (1956). Colorimetric methods for determination of 
sugar and related substances. Anal. Chem.;28(3):350-356.

Snedecor, G. W. and Cochran, W. G. (1980). Statistical Methods. Oxford and J.B.H. publishing com. 7th edition, $593 \mathrm{p}$.

Tamara, V. R.; Nadezhda, G. K. and Natalya, A. M. (2005). Influence of soil application of biological and mineral fertilizers on the growth, yield, and fruit biochemical components of
'Charavnitsa' apple, and on some agrochemical soil characteristics. Acta Scientiarum Polonorum, Hortorum Cultus, 4, 59-67.

Zaghloul, A.E. and Knany, R.E. (2012). Effect of balanced fertilization and fertilizer levels on navel orange yield and fruit quality. Alexandria science exchange journal, Vol.33, No.1january-march, 4454. 
إستبدال 50\% من الأسمدة الكيماوية NPK عن طريق التسميد العضوى (الكمبوست) والتسميد الحيوى (مركب EM )

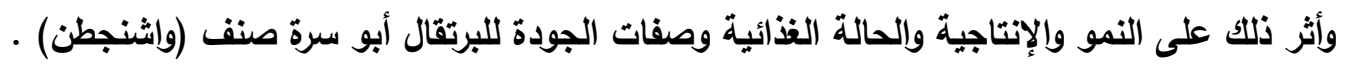

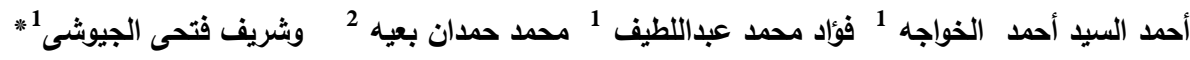

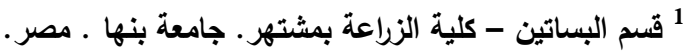

2قسم تكنولوجيا الحاصلات البستانية- المركز القومي للبحوث.

أجريت هذه الدراسة خلال موسمين متتاليين 2018 \&2019 علي أثنجار البرتقال أبو سرة (واثنجطن) عمر 9 سنوات المثمرة والمطعومة علي أصل النارنج وعلي مسافة زراعة 5x5م في أرض طميية تحت نظام الري السطحي في مزرعة خاصده بقرية المنزلة - مركز طوخت محافظة

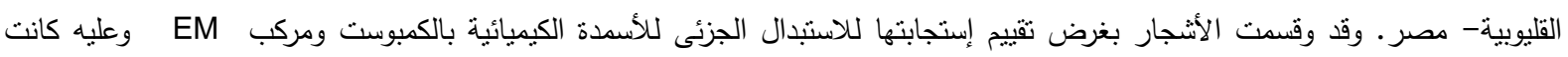

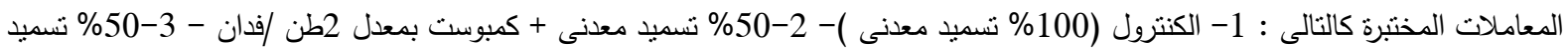

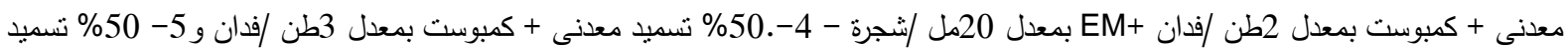
معدنى + كمبوست بمعدل 3طن /فدان EM+ بمعدل 20مل /شجرة . وقد استخدم التصميم التجريبي القطاعات الكاملة العشوائية بحيث كررت كل

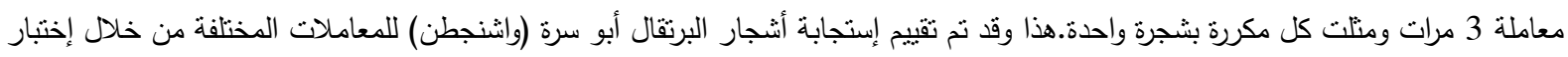

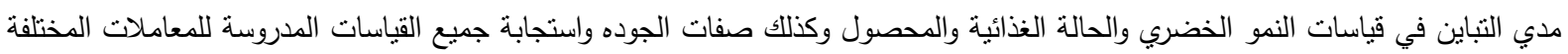
بدرجات متفاوتة وان كانت المعاملة الاولي ( 100\% ثنميد معدنى) هي الافضل في هذ الصدد يتساوي معها في التفوق مع معظم الصفات المدروسة

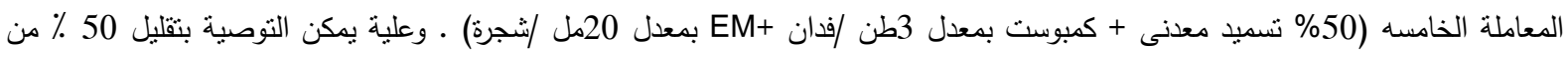

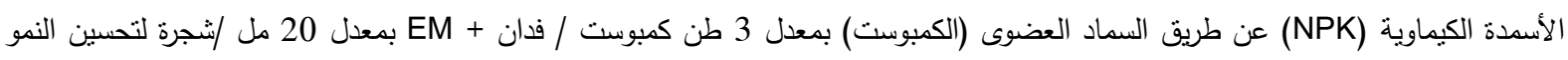
الخضري و المحتوى الكيماوي للأوراق والثزهير والإثمار والدحصول وجودة الثمار لأشجار البرتقال أبو سرة (واثنجطن) كمحاولة لنقليل استخدام

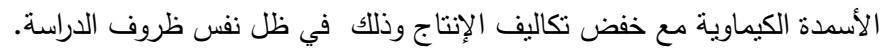

